\title{
Readiness Beauty Education Students in Implementing the Virtual Work Show 2020
}

\author{
Maria Krisnawati ${ }^{1}$, Delta Apriyani ${ }^{2}$ \\ \{mariakrisnawati@mail.unnes.ac.id\} \\ Family Welfare, Universitas Negeri Semarang, Indonesia ${ }^{12}$
}

\begin{abstract}
The Covid 19 pandemic has made all parties involved in learning and the field of education learn to utilize technology so that at the same time they can prepare themselves for the era of technological advances in education. So even though the Covid 19 epidemic occurred, the educational process was still carried out, as was the course of the Title of Work. Every year the Work Show is held on a stage by inviting many people, but for 2020 the work title will be held virtually. So, this study aims to determine the readiness of Beauty education students in implementing the Virtual Work Show 2020. This research uses descriptive quantitative, data collection using questionnaires and data analysis using descriptive percentages. The results showed that the readiness of Beauty education students to carry out the Virtual Work Show was very good.
\end{abstract}

Keywords: Beauty Education; Virtual Work; Covid 19

\section{Introduction}

The Covid-19 pandemic has had a tremendous impact on human life in the world. Every country in various ways is trying to solve this problem, including Indonesia. The Indonesian government is trying to be able to overcome the Covid-19 pandemic with various policies so that it can continue to protect its people. One of the policies is to limit social activities including closing schools and other learning places. Learning activities are then transferred to distance learning by relying on internet technology. With this pandemic, all parties involved in learning and in the field of education can learn to use technology so that at the same time they can prepare themselves for the era of technological advances in education. Schools as educational providers must be prepared to facilitate any changes regarding the education of their students. Behavioral education must become a strong foothold in the midst of technological developments and the accelerated flow of information.

Educational programs carried out by schools must really be conveyed to students, especially with online media, still the school must really pay attention to ethics as an educational institution. The emphasis on learning at home to students must be properly monitored so that teachers who teach through online media remain smooth and smart in delivering lessons that must be understood by students. Distance learning steps should be as effective as possible. The teacher does not burden students with tasks that are delivered in studying at home. The teacher is not only positioned as a transfer of knowledge, but still prioritizes "ing ngarso sung tulada, ing madya mangun karsa, tut wuri handayani".

So even though the Covid 19 epidemic occurred, the educational process was still carried out, as was the course of the Work Show. The aim of the Work Show course is to master the 
knowledge and skills of organizing fashion shows and display of work in accordance with the theme of the title of work which is based on an honest, creative and innovative attitude to realize conservation insights. Every year the Work Show is held on a stage by inviting many people, but for 2020 the work title will be held virtually. Based on the background above, this study aims to determine the readiness of Beauty education students in implementing the Virtual Work Show 2020.

Performance according to Bandi, et al. (2009: 309) is the result of a work of art that was created to be shown to the public to show the ability of an artist. Performances are activities carried out by artists to convey their ideas or ideas to the public through the media of art works. According to Bandi, et al. (2009: 310) The function of the performance is a vehicle to develop people's appreciation of art. The form of appreciation consists of creative appreciation and affective appreciation. At the level of creative appreciation, it leads the observer to use ratio in responding to the problems they face, whereas affective appreciation involves more feelings so that the observer feels and experiences empathy and gets a sense of satisfaction than people who only do creative appreciation.

According to Bandi, et al. (2009: 313) in organizing exhibitions and performances there are requirements that must be met, including: (1). Artwork to be exhibited (2) The committee for organizing the performance, (3). Performance visitors (4). Place of performance. It is very important that the artwork to be exhibited is planned in advance so that the results obtained can be maximized and can entertain visitors. The committee is the most important aspect in preparing a work of art or performance because the committee is responsible for managing events from planning, events, to activity reports that must be accounted for.

Performance planning stages according to Bandi, et al. (2009: 319), including: (1). Determining goals so that a plan needs to be designed systematically and logically so that when its implementation runs smoothly. It is better if the purpose of holding exhibitions in schools is specifically determined, whether to sharpen the problem of student appreciation, whether to develop a love for culture, or to provide criticism of other people's work, and so on (2). Determining the theme of exhibitions and performances serves to clarify the goals to be achieved, the theme to give breath to the activities, and the existence of the theme can clarify the mission of the exhibition to be carried out, (3). Arranging the structure and duties of the exhibition and performance committee. Organizing exhibitions and performances will run smoothly if it is carried out by an organizational structure of the committee. The arrangement of the exhibition committee organizational structure is adjusted to the level of needs, situations and conditions of the school.

Usually, the committee structure of an exhibition consists of a core committee and is assisted by sections, (4). Determining the time and place determining the time of the exhibition must be followed and witnessed by all citizens. So it can be concluded that performances are works of art produced by someone to be shown to the wider community for various purposes such as reminding the importance of culture and art, increasing knowledge for the wider community, and artists can disseminate their work for the public to see. Performances are carried out using management principles, namely planning, organizing implementation, monitoring.

The readiness for organizing the title of work includes planning, organizing, implementing and evaluating. Planning is planning the objectives, background, location, time, and technical implementation. Organizing by forming a committee (starting from the controller, the person in charge to the sections) by first making an inventory of the things to be done in detail, and dividing all work and appointing people in charge so that good cooperation can be achieved and not blame each other one another in the event of deviations from a plan 
that has been prepared and determined previously. The implementation during the design process until the rehearsal and the D-day of the work, needs strategy, coordination and communication with other sections. Supervision means the stage of control (evaluation) and assessment starting from all planning activities to implementation, if there is something deviation from planning. Internal and external assessment. The final action of all activities is the final assessment / evaluation of each section in the form of a report.

According to Slameto (2003: 113) readiness is the overall condition of a person that makes him ready to respond / answer in a certain way to a situation. The adjustment of the conditions at one point in time will affect or tend to respond. Slameto (2003: 113) explains that the condition includes at least 3 aspects, namely: (1). Mental and emotional physical condition, (2). Needs motives and goals, (3). Skills, knowledge and other understanding that has been learned. These three aspects (which a person has) will influence him and fulfill / do something or become a tendency to do something. The physical condition referred to is for example a temporary physical condition (fatigue, condition, sensory organs, etc.) and a permanent one (disability). Mental condition concerns intelligence. Gifted children (who are above 10 normal) are allowed to carry out higher tasks. Emotional conditions also affect readiness to do something, this is because it has something to do with motives (positive incentives, negative incentives, gifts, punishments) and it will affect readiness to learn.

Motives have a very important role in every human action or action which can be interpreted as the background of human behavior itself. Motive is a certain condition, in humans which causes humans to behave for a purpose. Encouragement and need can form a motive for taking action to achieve goals.

\section{Methodology}

This research uses descriptive quantitative. Quantitative descriptive research is a research activity that aims to test a theory, make predictions, provide a statistical picture to show the relationship between variables, and confirm facts. Descriptive research is a form of research from the most basic methods. Intended to describe or describe existing phenomena, either natural phenomena or human engineering (Sugiyono, 2011: 297). Data collection uses a questionnaire, which contains questions that are relevant to the readiness to carry out the title of Virtual Beauty education Work in 2020. According to Sugiyono (2011: 61) population is a generalization area consisting of objects or subjects that have certain qualities and characteristics that are determined by them to be studied and then draw conclusions. The population in this study included all active students of Beauty Education class 2017 totaling 49 people.

The sample is a part or representative of the population studied. The sample is part and the number and characteristics of the population (Sugiyono, 2011: 62). To determine the sample, purposive sampling was used, the sample unit contacted was adjusted according to certain criteria applied based on the research objectives or research problems. (Sugiyono, 2011: 64). This research is related to the readiness to carry out the 2020 virtual work show, the sample used is the Beauty Education students' class of 2017 who are taking the Master of Work course with the schedule code 2019201844 totaling 46 people.

The data collection technique used was a questionnaire research instrument (questionnaire). The research instrument is a way of scoring or coding each question item. The research instrument is a tool for researchers in collecting data (Suharsimi Arikunto, 2009: 
134). This study uses a questionnaire instrument. According to Sugiono (2011: 142), data collection techniques using questionnaire research instruments are data collection techniques that are carried out by giving a set of questions or written statements to respondents to answer. The information is about the readiness of Beauty education students to carry out the Virtual Work Show. The way to develop the instrument was done by arranging the grid. The arrangement of the instrument grid refers to the scope of Beauty education students' readiness to carry out the 2020 Virtual Work Show. According to Slameto, readiness includes physical, mental and emotional conditions, needs, motivation and goals as well as skills and knowledge. Other readiness factors are costum and property. From the variables above, it is developed into an indicator then it is developed again into 35 questions.

The questions in this questionnaire are filled in by choosing one of the 4 alternative answers that are considered suitable according to the actual conditions. The four alternative answers:
a. Strongly Agree / Very good the score is 4 (four)
b. Agree / Good the score is 3 (three)
c. Quite Agree / Poor, the score is 2 (two)
d. Disagree / Not Good, the score is 1 (one)

Validity with Expert Judgment, this stage involves experts in validating this instrument, namely experts in the field of education and learning evaluation, experts in the field of beauty education teaching and event management experts, the results of expert judgment are 5 reductions in invalid questions. The research instrument has also been tested, with the aim of knowing whether it can be used for data collection or not. The results of the reliability calculation of the main instrument field trial score data as a whole have a Cronbach Alpha reliability coefficient value of 0.901 . According to Miller (2008: 87), the instrument is said to have a good reliability coefficient having a reliability coefficient of 0.80 or more.

The data from the questionnaire in this study is quantitative data which will be analyzed descriptively in percentage with the steps according to Riduan (2004: 71-95) as follows:

a. Calculating the value of the respondent and each aspect or sub variable.

b. Recap the value.

c. Calculate the average value.

d. Calculating the percentage using the formula

To determine the level of these criteria, then the score obtained (in $\%$ ) with percentage descriptive analysis was consulted with the criteria table.

Table 1. Criteria for Percentage Descriptive Analysis

\begin{tabular}{ccc}
\hline No. & Percentage & Criteria \\
\hline 1. & $>75 \%-100 \%$ & Very good \\
2. & $>50 \%-75 \%$ & Good \\
3. & $>25 \%-50 \%$ & Pretty good \\
4. & $1 \%-25 \%$ & Not good \\
\hline
\end{tabular}




\section{Result and Discussion}

3.1 Readiness of Beauty education Students to Face 2020 Virtual Work Degree

a. Physical, Mental and Emotional Conditions

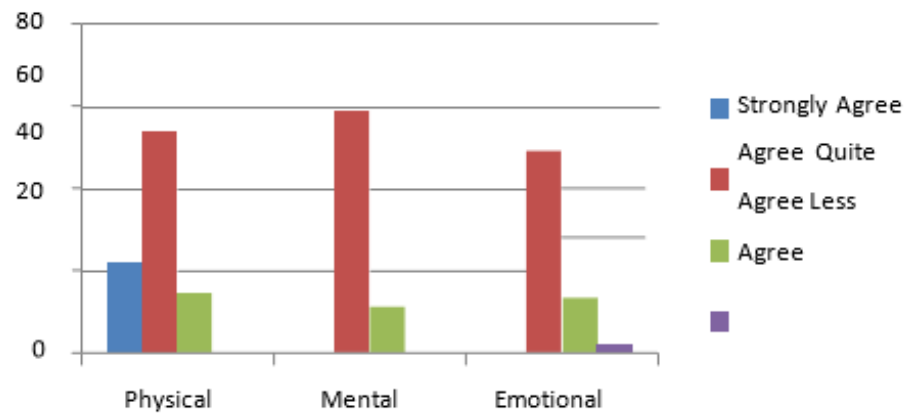

Fig 1. Graph of Physical, Mental and Emotional Conditions

b. Needs, Motivation, and Purpose

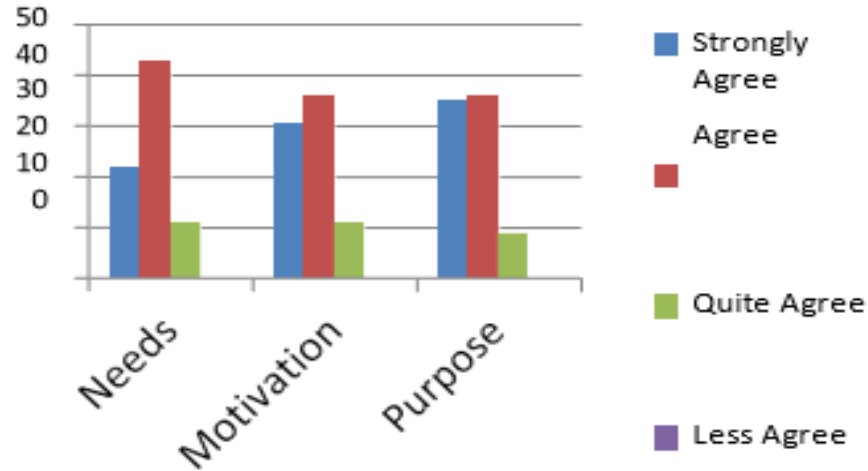

Fig 2. Graph of Needs, Motivation, and Purpose

c. Skill and Knowledge

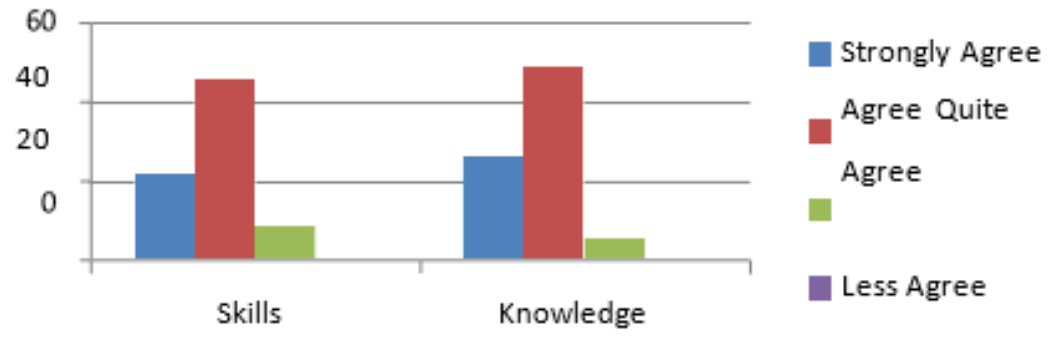

Fig 3. Graph of Skill and Knowledge 
d. Costume Readiness and Equipment and Property

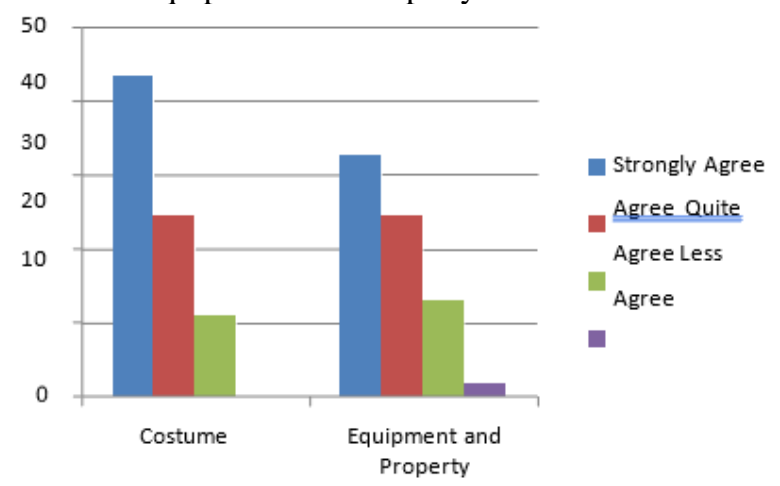

Fig 4. Graph of Costume Readiness and Equipment and Property

According to Slameto (2003: 113), the implementation of a Virtual Work Show requires good readiness. This readiness is a physical, mental and emotional condition. The research data shows that readiness with physical condition indicators is $89.67 \%$. This data means that Beauty education students have very good physical health which greatly supports their readiness to face the Virtual Work Show. Virtual Work Show require very good physical condition, because the work to be done is very much and heavy. The work starts from planning, production, implementation to the final stage. The research data shows that readiness in terms of mental condition indicators is $69.57 \%$ with good criteria. This shows that the mental readiness of students is lower than physical readiness. The first experience of implementing a Virtual Work Show resulted in students experiencing a little pressure. The pressure in question is a feeling of fear if there is a failure to carry out the event.

The emotional condition is $64.12 \%$, indicating that students have a good emotional condition. This readiness can support the implementation of the Work Show which requires hard effort and starting preparation, production and implementation will definitely experience problems. With a good emotional condition, problems, obstacles and challenges can be resolved properly. The readiness of the need's indicator is $74.99 \%$. This shows that students have a great need to realize a Virtual Work Show, because this event is an opportunity where students will present a final work that is designed. Another requirement is that students need grades for passing the Work Show course.

The motivation of students in readiness to carry out a virtual work show was $77.19 \%$. This means that students have high motivation to carry out the event. This encouragement is very important because it can give the spirit to carry out the work show well, so that tiring work is done well and becomes fun. The readiness to carry out the Virtual Work Show based on objectives is $79.39 \%$ with good criteria. High needs and motivation are able to encourage students to achieve the goal of carrying out the Virtual Work Show well. Student skills to support readiness to face Virtual Work Show of $76.09 \%$, with good criteria. Students already have the skills they have acquired from the experience of previously taken courses. Students also have very good knowledge, namely $82.42 \%$ with very good criteria, because students can learn from various sources. Sources of knowledge are obtained from lecturers, friends, books, the internet, YouTube and other media.

The appearance of a good virtual work show requires good costume readiness (Bandi, et al, 2009: 313). Therefore, the readiness of students to be able to provide costume is 78.81 with very good criteria. Students want to show their best work, so they prepare a custom to support 
the appearance of the Virtual Work Show model. In addition to the costume, students also prepare makeup and cosmetics equipment, camera tools and a place or studio to support taking product videos to be shown in the Virtual Work Show. The availability of equipment, materials and property is $71.74 \%$, meaning that students can provide equipment and property properly.

Based on the readiness indicators above, combined with an average of $76.40 \%$, which means that beauty education students have very good readiness to carry out the Virtual Work Show in terms of indicators of physical, mental, emotional, needs, motivation, goals, skills, knowledge, costume and property.

\section{Conclusion}

Based on the results of research and discussion, the conclusion is the readiness of Beauty education students to carry out the Virtual Work Show is very good. Readiness in terms of physical condition is very good, mental condition is strong, emotional condition is good, needs are high, motivation and goals are very high, skills and knowledge are very adequate, readiness of costume is very good and property is good.

\section{References}

[1] Bandi, DKK. (2009) Pembelajaran Seni Budaya dan keterampilan. Jakarta. Direktora Jenderal Pendidikan Islam Departemen Agama Republik Indonesia.

[2] Buana, Dana Riksa. (2020) Analisis Perilaku Masyarakat Indonesia dalam Menghadapi Pandemi Virus Corona (Covid-19) dan Kiat Menjaga Kesejahteraan Jiwa," Salam: Jurnal Sosial dan Budaya Syar-i, Volume 7, No. 3.

[3] Eka Agung Seputra, Yulius. 2014. Manajemen dan Perilaku Organisasi. Yogyakarta: Graha Ilmu Natoradjo, Sulyus. (2011). Event Organizing Dasar-dasar Event Management. Jakarta: PT Gramedia Pustaka Utama.

[4] Rohmah, S.N. (2020) Adakah Peluang Bisnis di Tengah Kelesuan Perekonomian Akibat Pandemi Corona?," Adalah: Volume. 4, No. 1 (2020).

[5] Slameto. Belajar dan Faktor-faktor yang Mempengaruhinya. Jakarta Pt Rineka Cipta Sudjana. (2006).Metode Statistika. Bandung Penerbit Tarsito

[6] Sugiyono. (2012). Metode Penelitian Kombinasi (Mixed Mothods). Bandung Penerbit Alfabeta.

[7] Yunus, N.R.; Rezki, Annissa. (2020) "Kebijakan Pemberlakuan Lock Down Sebagai Antisipasi Penyebaran Corona Virus Covid-19," Salam: Jurnal Sosial dan Budaya Syar-i, Volume 7, No. 3. 